\title{
Tomographic mapping of the hard palate and overlying mucosa
}

\author{
Mariana Marquezan ${ }^{(a)}$ \\ Lincoln Issamu Nojima(a) \\ Amanda Osório Ayres de Freitas ${ }^{(a)}$ \\ Carolina Baratieri(a) \\ Matheus Alves Júnior ${ }^{(a)}$ \\ Matilde da Cunha Gonçalves \\ Noiima ${ }^{(a)}$ \\ Mônica Tirre de Souza Araújo(a)
}

(a) Department of Pedodontics and Orthodontics, Federal University of Rio de Janeiro (UFRJ), Rio de Janeiro, RJ, Brazil.

Declaration of Interests: The authors certify that they have no commercial or associative interest that represents a conflict of interest in connection with the manuscript.

\section{Corresponding author:}

Mariana Marquezan

E-mail: marianamarquezan@gmail.com

Received for publication on Sep 26, 2011 Accepted for publication on Dec 06, 2011
Abstract: The aim of this study was to measure the thickness of the hard palate and its overlying mucosa using cone-beam computed tomography (CBCT), for purposes of miniscrew placement. The sample comprised 36 CBCT scans of patients aged 12 to 52 years from a database of the Orthodontics Department of the Federal University of Rio de Janeiro. Paracoronal views of the palatal region were reconstructed at 4, 8, 16 and $24 \mathrm{~mm}$ posterior to the incisive foramen. In each reconstruction measurements were taken at the suture, $3 \mathrm{~mm}$ and $6 \mathrm{~mm}$ bilaterally to it. Wilcoxon's test verified the differences between the selected regions. Total bone height decreased from the anterior to the posterior region. In cross sections 4, 16 and 24, bone height decreased from the suture laterally to the $3 \mathrm{~mm}$ region and then increased in the $6 \mathrm{~mm}$ region. The cortical thickness does not seem to be a concern because it presented a mean thickness of at least $1 \mathrm{~mm}$ at all sites evaluated. The measurements of the mucosa thickness decreased from lateral to median and from anterior to posterior regions. The most suitable areas for miniscrew placement in the palate are located $4 \mathrm{~mm}$ posterior to the incisive foramen, in the median or paramedian regions $3 \mathrm{~mm}$ adjacent to the suture.

Descriptors: Orthodontic Anchorage Procedures; Palate; Cone-Beam Computed Tomography.

\section{Introduction}

Dental implants were introduced as skeletal anchorage resources in Orthodontics in the mid-80s, but it was in 1997 that Kanomi ${ }^{1}$ introduced mini-implants, a variation of the surgical screws. Mini-implants are commonly inserted in the interseptal region, retromolar area and palate. The palate is probably the most favorable area for miniscrew placement because there is easy access, low risk of damaging important anatomical structures and there is attached keratinized tissue along its entire length..$^{2-6}$ Moreover, mini-implants placed in these regions have the advantage of not interfering in the tooth movement. ${ }^{7}$ This area is chosen for placing mini-implants when forward or backward movements of posterior teeth are required, ${ }^{8}$ intrusion of maxillary teeth ${ }^{9,10}$ or traction of impacted maxillary teeth. ${ }^{11}$

In order to indicate the most appropriate mini-implant for each site, it is necessary to know which devices are available on the market and to have a detailed knowledge of the local anatomy. Cortical bone thickness at the site of mini-implant placement is a factor to consider for achieving 
their primary stability. ${ }^{12,13}$ In addition to knowing the cortical bone thickness in this region, it is necessary to know the total bone thickness in order to choose the appropriate mini-implant length to avoid perforations in the nasal cavity floor..$^{2-4,7,14-17}$ Knowledge of soft tissue thickness also helps in determining the overall implant length ${ }^{18}$ and implant collar height. ${ }^{19}$

Clinical examination, panoramic and cephalometric radiographs have limitations when assessing the amount of bone tissue in the palate. ${ }^{14}$ Recent studies have shown that computed tomography is a good method to evaluate the bone site most suitable for mini-implant placement ${ }^{2,4,15}$ since there is no distortion and superimposition of images. Cone-beam computed tomography (CBCT) is also a good tool to evaluate soft tissue thickness. ${ }^{20-22}$

The aim of this study was to evaluate the thickness of cortical bone, total bone and mucosa in the palatine suture and paramedian areas using CBCT to verify the most suitable areas for miniscrew placement.

\section{Methodology}

The sample consisted of 36 CBCT scans from the database of patients from the Orthodontics Department of the Federal University of Rio de Janeiro. Patients of both genders ( 8 male) who had tomography performed as part of their orthodontic exams were included. Their age range was 12 to 52 years (mean age $23.61 \pm 11.89$ ), so that the sample comprised growing patients and adults in order to evaluate the influence of age on palatal tissues. The exclusion criteria were:

- presence of craniofacial malformations or syndromes,

- previous history of trauma or surgery in the study area, and

- CBCT scans in which the tongue was resting against the palate, hampering the measurement of the palatal mucosa.

This study was approved by the Research Ethics Committee of the Institute of Public Health Studies, Federal University of Rio de Janeiro (no. 61/2010), and patients signed a document allowing the use of their tomographic exams for this study.

Data were obtained using a 3D cone-beam volume scanner (i-CAT Cone Beam 3-D Imaging System, PA, USA). The following settings were used:

- $22 \mathrm{~cm}$ field of view,

- $120 \mathrm{kV}$,

- $47 \mathrm{~mA}$,

- exposure time $30 \mathrm{~s}$ and

- slice thickness $0.4 \mathrm{~mm}$.

Multiplanar reconstruction of the head, orientation and measurements were performed with Dolphin Imaging Software (version 11, Chatsworth, CA, USA). Orientation was established by three reference planes:

- the axial plane, passing through the right and left Orbitale points as well as the right Porion;

- the coronal plane, passing through the left and right Porion perpendicular to the chosen axial plane; and

- the sagittal plane, passing through the Nasion point, perpendicular to the chosen axial and coronal planes..$^{23,24}$

Twenty points in each patient's palate were chosen for measurements ${ }^{16}$ (Figure 1). The first step was to locate the incisive foramen. This was tracked by sagittal and axial views simultaneously (Figure 2).

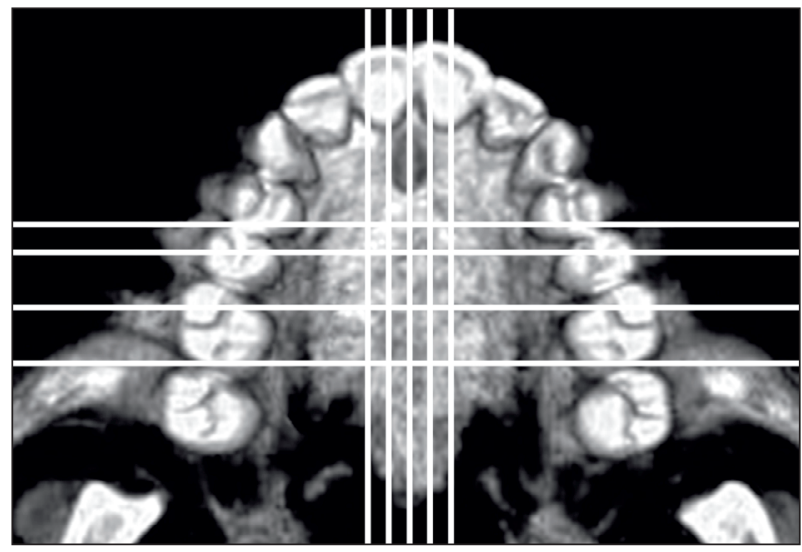

Figure 1 - Occlusal view of a palate in CBCT. The horizontal lines represent the sites of coronal cross sections: 4, 8 , 16 and $24 \mathrm{~mm}$ posterior to the incisive foramen. The vertical lines represent the median and paramedian regions evaluated ( $3 \mathrm{~mm}$ and $6 \mathrm{~mm}$ laterally to the suture). Their intersections represent the twenty points evaluated. 
Paracoronal views of the palatal region were reconstructed at 4, 8, 16 and $24 \mathrm{~mm}$ posterior to the distal wall of the incisive foramen. In each reconstruction, measurements were taken at the mid-palatal suture, $3 \mathrm{~mm}$ and $6 \mathrm{~mm}$ bilaterally to it (Figure 3). Measurements were taken in the vertical direc$\operatorname{tion}^{16}$ (Figure 3) and the three tissues (cortical, trabecular bone and overlying mucosa) were measured based on gray level differences. The cortical bone could not be evaluated separately from total bone in the median region because the suture imbrications make it hard to distinguish cortical and trabecular bone. Measurements were recorded in millimeters, tabulated and submitted to statistical analyses. They were performed by a single calibrated examiner twice with a 2 -week interval. The reliability of measurements was satisfactory (for total bone measurement ICC $=0.968$; for cortical thickness measurement ICC $=0.744$; for mucosa ICC $=0.924$ ).

Analyses were performed using the Statistical Package for the Social Sciences (version 17, SPSS Inc., Chicago, IL, USA). Shapiro-Wilk and Levene tests were used to assess the normal distribution and homogeneity of variables. The nonparametric Wilcoxon test verified whether measurements varied according to the paracoronal view and the paramedian regions evaluated. The Spearman test was performed to verify whether age had any influence on

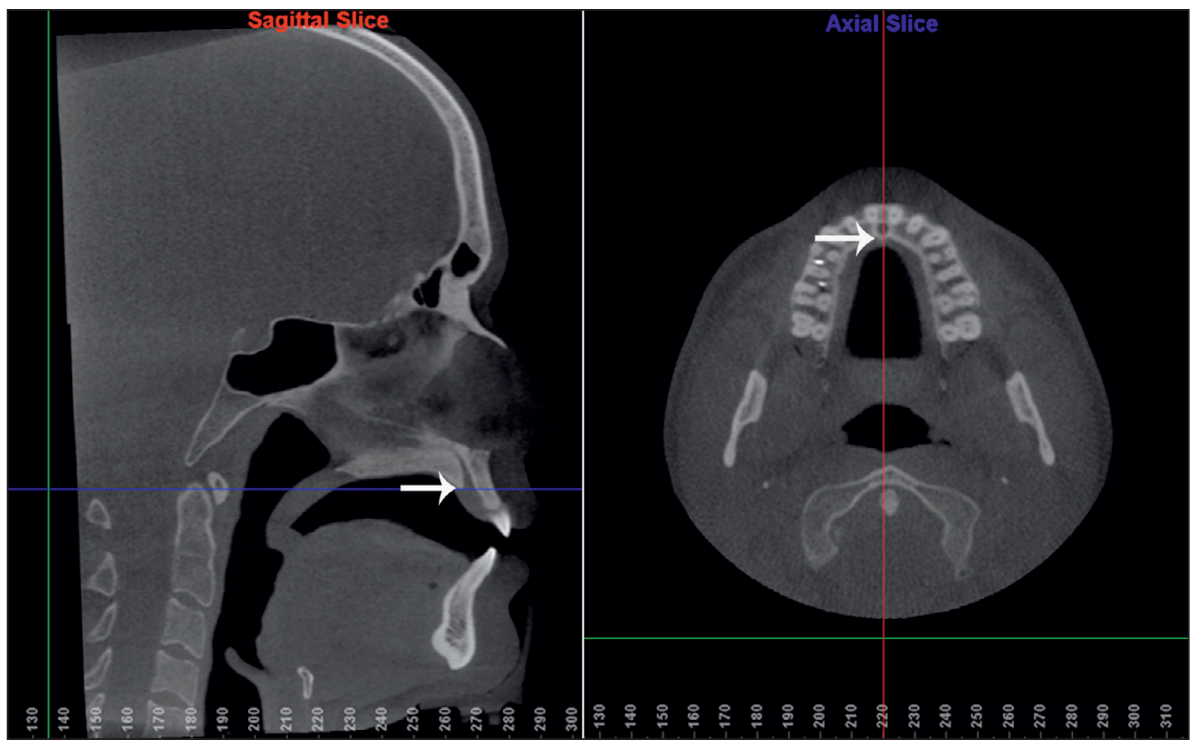

Figure 2 - Sagittal and axial slices generated simultaneously by Dolphin Imaging Software were used to determine the posterior wall of the incisive foramen, indicated by the white arrows.

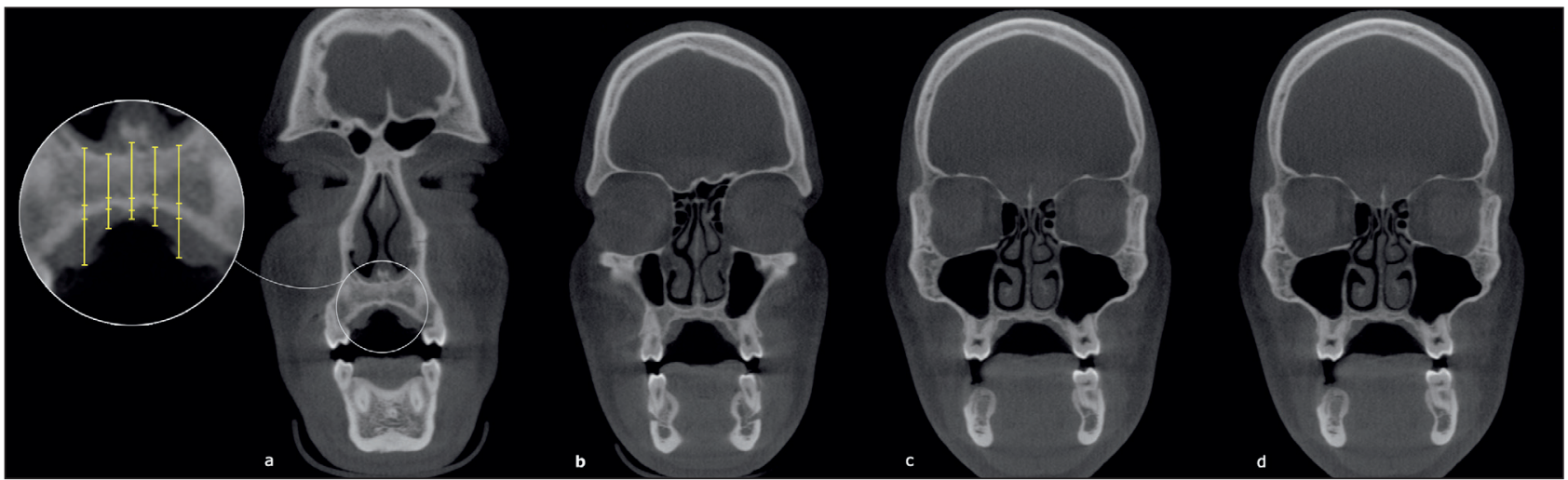

Figure 3 - Coronal slices reconstructed of $4(\mathbf{a}), 8(\mathbf{b}), 16(\mathbf{c})$ and $24(\mathbf{d}) \mathrm{mm}$ posterior to the distal wall of the incisive foramen. These cross sections were used for palatal tissue measurements. The detail shows how measurements were taken in each reconstruction at the median suture, 3 and $6 \mathrm{~mm}$ laterally to it. 
the measurements.

\section{Results}

Descriptive statistics are presented in Tables 1 and 2. The total bone measurement decreased from the anterior to posterior regions up to section 16 ( $\mathrm{p} \leq 0.05)$. In cross sections 4,16 and 24 , measurements of the $6 \mathrm{~mm}$ paramedian region were similar to those of the suture, but differed from those in the $3 \mathrm{~mm}$ region, where values were lower $(\mathrm{p} \leq 0.05)$. Cortical thickness remained similar throughout the median and paramedian regions. However, this measurement was smaller in region $6 \mathrm{~mm}$ than those in the $3 \mathrm{~mm}$ sites in cross sections 16 and 24 $(\mathrm{p} \leq 0.05)$. In paramedian region 3 , the cortical thickness measurement showed no difference from the anterior to posterior regions. However, in paramedian region 6, cortical thickness measurements decreased from the anterior region (sections 4 and 8 ) to posterior region (sections 16 and 24) ( $\mathrm{p} \leq 0.05$ ). When evaluating mucosa measurements, the values decreased from the lateral to median sites, and were smaller at the suture $(\mathrm{p} \leq 0.05)$. A reduction was also observed from the anterior to posterior regions up to cross section 16 ( $\mathrm{p} \leq 0.05)$. No correlation was found between the patients' age and palatal tissue measurements.

\section{Discussion}

Many studies have shown that the palate is a suitable area for miniscrew placement ${ }^{3,16}$ with emphasis on easy access ${ }^{2,3}$ and favorable distance from the roots, thus avoiding any damage to them ${ }^{2,3}$ or interference with tooth movement. ${ }^{7}$ This feature allows the insertion of large-diameter miniscrews (2 or $2.2 \mathrm{~mm}$ ), providing improved stability. ${ }^{25}$ In the palate, the big challenge is the length of miniscrews. There must be sufficient bone thickness to receive the functional part of the miniscrew, ranging from 6 to $12 \mathrm{~mm}$ in length, without perforating the nasal cavity..$^{2-4,7,14-17}$ The limited availability of palatal bone height was the reason for the development of

Table 1 - Descriptive analysis of palatal bone thickness (cortical and total bone) in the suture and paramedian regions at the four cross sections.

\begin{tabular}{|c|c|c|c|c|c|c|c|c|c|c|}
\hline & & \multicolumn{2}{|c|}{$6 \mathrm{~mm}$ right } & \multicolumn{2}{|c|}{$3 \mathrm{~mm}$ right } & \multirow{2}{*}{$\begin{array}{c}\text { suture } \\
\text { Total bone }\end{array}$} & \multicolumn{2}{|c|}{$3 \mathrm{~mm}$ left } & \multicolumn{2}{|c|}{$6 \mathrm{~mm}$ left } \\
\hline & & Total bone & Cortical & Total bone & Cortical & & Total bone & Cortical & Total bone & Cortical \\
\hline Cross section 4 & $\begin{array}{c}\text { mean } \\
(\mathrm{SD})\end{array}$ & $\begin{array}{c}7.28 \\
(2.87)\end{array}$ & $\begin{array}{c}1.85 \\
(0.53)\end{array}$ & $\begin{array}{l}6.75 \\
(2.5)\end{array}$ & $\begin{array}{c}1.58 \\
(0.39)\end{array}$ & $\begin{array}{c}7.58 \\
(3.22)\end{array}$ & $\begin{array}{c}6.87 \\
(2.45)\end{array}$ & $\begin{array}{l}1.5 \\
(0.46)\end{array}$ & $\begin{array}{c}7.29 \\
(3.09)\end{array}$ & $\begin{array}{l}1.6 \\
(0.57)\end{array}$ \\
\hline Cross section 8 & $\begin{array}{c}\text { mean } \\
\text { (SD) }\end{array}$ & $\begin{array}{c}3.53 \\
(1.9)\end{array}$ & $\begin{array}{l}1.7 \\
(0.51)\end{array}$ & $\begin{array}{c}3.77 \\
(1.74)\end{array}$ & $\begin{array}{l}1.9 \\
(1.01)\end{array}$ & $\begin{array}{l}5.69 \\
(1.6)\end{array}$ & $\begin{array}{c}3.88 \\
(1.82)\end{array}$ & $\begin{array}{c}1.72 \\
(0.8)\end{array}$ & $\begin{array}{c}3.91 \\
(2.09)\end{array}$ & $\begin{array}{c}1.77 \\
(0.58)\end{array}$ \\
\hline Cross section 16 & $\begin{array}{c}\text { mean } \\
(\mathrm{SD})\end{array}$ & $\begin{array}{c}1.71 \\
(0.75)\end{array}$ & $\begin{array}{c}1.32 \\
(0.41)\end{array}$ & $\begin{array}{c}2.13 \\
(1.10)\end{array}$ & $\begin{array}{c}1.54 \\
(0.45)\end{array}$ & $\begin{array}{c}5.13 \\
(1.65)\end{array}$ & $\begin{array}{c}2.40 \\
(1.12)\end{array}$ & $\begin{array}{c}1.69 \\
(0.61)\end{array}$ & $\begin{array}{c}1.94 \\
(1.0)\end{array}$ & $\begin{array}{l}1.5 \\
(0.54)\end{array}$ \\
\hline Cross section 24 & $\begin{array}{c}\text { mean } \\
(\mathrm{SD})\end{array}$ & $\begin{array}{c}1.65 \\
(0.67)\end{array}$ & $\begin{array}{c}1.34 \\
(0.39)\end{array}$ & $\begin{array}{c}2.47 \\
(1.14)\end{array}$ & $\begin{array}{l}1.9 \\
(0.71)\end{array}$ & $\begin{array}{c}5.48 \\
(1.61)\end{array}$ & $\begin{array}{c}2.33 \\
(1.14)\end{array}$ & $\begin{array}{c}1.73 \\
(0.82)\end{array}$ & $\begin{array}{c}1.45 \\
(0.66)\end{array}$ & $\begin{array}{c}1.12 \\
(0.44)\end{array}$ \\
\hline
\end{tabular}

Table 2 - Descriptive analysis of mucosa thickness in the suture and paramedian regions at the four cross sections.

\begin{tabular}{l|c|c|c|c|c|c}
\hline \multicolumn{2}{|c|}{} & $6 \mathrm{~mm}$ right & $3 \mathrm{~mm}$ right & suture & $3 \mathrm{~mm}$ left & $6 \mathrm{~mm}$ left \\
\hline Cross section 4 & $\begin{array}{c}\text { mean } \\
(\mathrm{SD})\end{array}$ & $5.33(1.59)$ & $3.38(1.03)$ & $2.92(1.27)$ & $3.37(1.08)$ & $5.19(1.47)$ \\
\hline Cross section 8 & $\begin{array}{c}\text { mean } \\
(\mathrm{SD})\end{array}$ & $3.98(1.16)$ & $2.63(0.83)$ & $2.06(0.95)$ & $2.8(1.08)$ & $4.8(1.92)$ \\
\hline Cross section 16 & $\begin{array}{c}\text { mean } \\
\text { (SD) }\end{array}$ & $2.86(0.87)$ & $2.04(0.83)$ & $1.53(0.7)$ & $1.9(0.84)$ & $3.32(1.29)$ \\
\hline Cross section 24 & $\begin{array}{c}\text { mean } \\
\text { (SD) }\end{array}$ & $2.54(0.73)$ & $1.75(0.58)$ & $1.33(0.59)$ & $1.82(0.82)$ & $3.0 \quad(1.03)$ \\
\hline
\end{tabular}


special short palatal implants for orthodontic anchorage ( 3 to $6 \mathrm{~mm}$ long). ${ }^{14}$ Nowadays conventional miniscrews can be used if the local anatomy is known.

A risky region for palatal implant placement is one with a height of less than $4 \mathrm{~mm},{ }^{2,3}$ because the shortest endosseous part of this implant is $3 \mathrm{~mm}$ long and a safety margin of $1 \mathrm{~mm}$ is recommended. ${ }^{4}$ In view of this statement, cross section 4 is safe in both the suture and paramedian regions. In the other cross sections, only the midsagittal region presented bone height of over $4 \mathrm{~mm}$. Nevertheless, based on the assertion that "the lower the angle between the plane of the anterior and posterior nasal spine and the implant axis, the wider the bone available", 7 we believe that the paramedian regions at cross section 8 could also be suitable when small implants are used and inserted with angulation. The paramedian regions at cross sections 16 and 24 are undoubtedly risky. The hard palate area posterior to $12 \mathrm{~mm}$ from the incisive foramen has previously been shown to be unsuitable for implant insertion ${ }^{15}$ and it is well known that total bone thickness decreases from the anterior to posterior regions. , $^{2,7,15-17}$ The region of the midsagittal suture is an exception because additional height is provided by the nasal crest. In all of the cross sections, this region was shown to be at least $5 \mathrm{~mm}$ thick, in agreement with $\mathrm{Kang}^{3}$ and Wehrbein. ${ }^{14}$

The safe and risky regions for miniscrew placement differ slightly from those for palatal implants. The endosseous part of palatal implants varies from 3 to $6 \mathrm{~mm}$ in length while the shortest miniscrew is $6 \mathrm{~mm}$ long. Nowadays, miniscrews are preferred to palatal implants because they are easier to insert, the possibility of immediate loading (it is not necessary to wait for osteointegration), and better healing after their removal. Thus, the total bone length is more critical. In this study, cross section 4 presented adequate total bone volume to receive a 6 - $\mathrm{mm}$ long miniscrew. The suture was also a suitable place in all of the cross sections, considering the possibility of inserting the miniscrew with angulation.

As regards the lateral direction, a decrease in total bone thickness was found from the suture to paramedian region $3 \mathrm{~mm}$ and it increased from there on up to paramedian region $6 \mathrm{~mm}$ in sections 4, 16 and 24 (in section 8 the paramedian regions 3 and $6 \mathrm{~mm}$ presented no differences). Similar findings were observed by $\mathrm{Gracco}^{16}$ in the anterior sections (4 and 8). Kang, ${ }^{3}$ however, verified a decrease from the central to lateral regions.

If care is taken during the planning of miniscrew placement in palate, the risk of nasal floor perforation is reduced. However, if a slight bone perforation occurs, the thickness of the nasal mucosa can prevent an open connection between the nasal and mouth cavities. ${ }^{14}$

Considering the cortical thickness, in paramedian regions $6 \mathrm{~mm}$ away from the suture, the cortical decreased from the anterior (cross sections 4 and 8 ) to posterior regions (16 and 24 sections), in agreement with Baumgaertel. ${ }^{17}$ In paramedian regions $3 \mathrm{~mm}$ away from the suture, however, no difference was observed. The cortical bone thickness in the palate does not seem to be a worrying aspect when choosing the ideal site for miniscrew placement because all of the sites evaluated in this study presented a thickness of over $1 \mathrm{~mm}$, adequate for primary stability. ${ }^{13,26}$ The cortical bone was not evaluated separately from total bone at the suture because of the difficulty in distinguishing cortical from trabecular bone in this region. Nevertheless, the literature supports the concept that the median area of the palate contains high-quality cortical bone. ${ }^{8}$

Whenever possible, the mini-implant should be inserted through the attached gingiva ${ }^{19}$ because it is believed that the risk of failure in nonkeratinized mucosa is higher than in keratinized mucosa ${ }^{18}$. Fortunately the entire area of the palate is lined with keratinized tissue, which is related to less inflammation. ${ }^{3}$ The length of the miniscrew should take into account the thickness of the mucosa, because a longer miniscrew should be selected to compensate for soft tissue thickness. ${ }^{27}$ Another option (and more appropriate, in the authors' opinion) is to choose a transmucosal neck compatible with the mucosa: the thicker the soft tissue, the longer the neck, as stated by Melsen. ${ }^{19}$ Another problem related to thick mucosa is miniscrew stability. The distance between the point of force application and the center of resistance of the screw will be greater than usual, thus 
generating a large moment when a force is applied, ${ }^{19}$ so a very thick fibromucosa with marked folds can be a contraindication for miniscrew placement. ${ }^{7}$ To prevent big moments of force, the suture and the paramedian region $3 \mathrm{~mm}$ away from the suture are preferable to the $6 \mathrm{~mm}$ region, where the mucosa is thicker. Despite the importance of verifying the thickness of mucosal tissue prior to miniscrew placement, the majority of the studies that mapped the palate do not consider this issue.

Alternatively to using CBCT to measure soft tissue thickness, a periodontal probe with an endodontic file stopper can be used under local anesthesia. An ultrasonic device (ultrasonic gingival-thickness meter) can also be used. ${ }^{27}$

The most suitable areas for receiving miniscrews are located along the suture or in cross section 4 ; in the paramedian region $3 \mathrm{~mm}$ lateral to the suture, because the total bone thickness is adequate for receiving an angulated miniscrew $6 \mathrm{~mm}$ long, the cortical is thicker than $1 \mathrm{~mm}$, providing adequate stability, and the mucosa is thinner than $3.5 \mathrm{~mm}$, reducing the moment when force is applied.

No correlation was found between palatal tissue measurements and the patients' ages. Bernhart ${ }^{2}$ previously found no association between age and the

\section{References}

1. Kanomi R. Mini-implant for orthodontic anchorage. J Clin Orthod. 1997 Nov;31(11):763-7.

2. Bernhart T, Vollgruber A, Gahleitner A, Dortbudak O, Haas R. Alternative to the median region of the palate for placement of an orthodontic implant. Clin Oral Implants Res. 2000 Dec;11(6):595-601.

3. Kang S, Lee SJ, Ahn SJ, Heo MS, Kim TW. Bone thickness of the palate for orthodontic mini-implant anchorage in adults. Am J Orthod Dentofacial Orthop. 2007 Apr;131(4 Suppl):S74-81.

4. King KS, Lam EW, Faulkner MG, Heo G, Major PW. Vertical bone volume in the paramedian palate of adolescents: a computed tomography study. Am J Orthod Dentofacial Orthop. 2007 Dec;132(6):783-8.

5. Moon SH, Park SH, Lim WH, Chun YS. Palatal bone density in adult subjects: implications for mini-implant placement. Angle Orthod. 2010 Jan;80(1):137-44. volume of bone in the palate. The mucosa thickness showed no correlation with age, disagreeing with Song, ${ }^{20}$ who observed an increase in palatal mucosa thickness as age progressed, possibly due to the increase of fat in this tissue.

The selection of cross sections $4,8,16$ and $24 \mathrm{~mm}$ distant from the incisive foramen was due to their reproducibility and use in a previous study. ${ }^{16}$ In order to make the evaluation more clinical, the tooth or the area between two teeth that appeared in each section was recorded. It was observed that in section 4 the first premolar was the most common tooth; in section 8 , the second premolars; in section 16 , the first molar; and in section 24 , the space between first and second molars.

The main contribution of this study to the literature is the evaluation of the thickness of the palatine hard and soft tissues together. However, it has limitations, such as the small sample size, and lack of homogeneity regarding gender and age of patients. Future studies should focus on improving these issues.

\section{Conclusion}

The most suitable areas for receiving miniscrews are located along the suture or in cross section 4 , in the paramedian region $3 \mathrm{~mm}$ lateral to the suture.

6. Lombardo L, Gracco A, Zampini F, Stefanoni F, Mollica F. Optimal palatal configuration for miniscrew applications. Angle Orthod. 2010 Jan;80(1):145-52.

7. Arcuri C, Muzzi F, Santini F, Barlattani A, Giancotti A. Five years of experience using palatal mini-implants for orthodontic anchorage. J Oral Maxillofac Surg. 2007 Dec;65(12):24927.

8. Kyung SH, Hong SG, Park YC. Distalization of maxillary molars with a midpalatal miniscrew. J Clin Orthod. 2003 Jan;37(1):22-6.

9. Lee JS, Kim DH, Park YC, Kyung SH, Kim TK. The efficient use of midpalatal miniscrew implants. Angle Orthod. 2004 Oct; 74(5):711-4.

10. Yao CC, Lee JJ, Chen HY, Chang ZC, Chang HF, Chen YJ. Maxillary molar intrusion with fixed appliances and miniimplant anchorage studied in three dimensions. Angle Orthod. 2005 Sep;75(5):754-60. 
11. Kuroda S, Yanagita T, Kyung HM, Takano-Yamamoto T. Titanium screw anchorage for traction of many impacted teeth in a patient with cleidocranial dysplasia. Am J Orthod Dentofacial Orthop. 2007 May;131(5):666-9.

12. Kim HJ, Yun HS, Park HD, Kim DH, Park YC. Soft-tissue and cortical-bone thickness at orthodontic implant sites. Am J Orthod Dentofacial Orthop. 2006 Aug;130(2):177-82.

13. Motoyoshi M, Yoshida T, Ono A, Shimizu N. Effect of cortical bone thickness and implant placement torque on stability of orthodontic mini-implants. Int J Oral Maxillofac Implants. 2007 Sep-Oct;22(5):779-84.

14. Wehrbein H, Merz BR, Diedrich P. Palatal bone support for orthodontic implant anchorage--a clinical and radiological study. Eur J Orthod. 1999 Feb;21(1):65-70.

15. Gahleitner A, Podesser B, Schick S, Watzek G, Imhof H. Dental CT and orthodontic implants: imaging technique and assessment of available bone volume in the hard palate. Eur J Radiol. 2004 Sep;51(3):257-62.

16. Gracco A, Lombardo L, Cozzani M, Siciliani G. Quantitative cone-beam computed tomography evaluation of palatal bone thickness for orthodontic miniscrew placement. Am J Orthod Dentofacial Orthop. 2008 Sep;134(3):361-9.

17. Baumgaertel S. Quantitative investigation of palatal bone depth and cortical bone thickness for mini-implant placement in adults. Am J Orthod Dentofacial Orthop. 2009 Jul;136(1):104-8.

18. Cheng SJ, Tseng IY, Lee JJ, Kok SH. A prospective study of the risk factors associated with failure of mini-implants used for orthodontic anchorage. Int J Oral Maxillofac Implants. 2004 Jan-Feb;19(1):100-6.
19. Melsen B. Mini-implants: Where are we? J Clin Orthod. 2005 Sep;39(9):539-47; quiz 31-2.

20. Song JE, Um YJ, Kim CS, Choi SH, Cho KS, Kim CK, et al. Thickness of posterior palatal masticatory mucosa: the use of computerized tomography. J Periodontol. 2008 Mar;79(3):406-12.

21. Januario AL, Barriviera M, Duarte WR. Soft tissue cone-beam computed tomography: a novel method for the measurement of gingival tissue and the dimensions of the dentogingival unit. J Esthet Restor Dent. 2008;20(6):366-73; discussion 74.

22. Barriviera M, Duarte WR, Januario AL, Faber J, Bezerra AC. A new method to assess and measure palatal masticatory mucosa by cone-beam computerized tomography. J Clin Periodontol. 2009 Jul;36(7):564-8.

23. Baratieri C, Nojima LI, Alves MJ, Souza MMG, Nojima MCG. Transverse effects of rapid maxillary expansion in Class II malocclusion patients: a cone-beam computed tomography study. Dental Press J Orthod. 2010 set-out; 15(5):89-97.

24. Alves M Jr, Baratieri C, Nojima LI. Assessment of mini-implant displacement using cone beam computed tomography. Clin Oral Implants Res. 2011 Oct 22(10):1151-6.

25. Carano A, Velo S, Leone P, Siciliani G. Clinical applications of the Miniscrew Anchorage System. J Clin Orthod. 2005 Jan;39(1):9-24; quiz 29-30.

26. Marquezan M, Souza MM, Araujo MT, Nojima LI, Nojima $\mathrm{M}$ da C. Is miniscrew primary stability influenced by bone density? Braz Oral Res. 2011 Oct;25(5):427-32.

27. Cha BK, Lee YH, Lee NK, Choi DS, Baek SH. Soft tissue thickness for placement of an orthodontic miniscrew using an ultrasonic device. Angle Orthod. 2008 May;78(3):403-8. 